\title{
A közigazgatás reformirányzatai Közép-Kelet-Európában ${ }^{1}$
}

\author{
SZAKOS JUDIT ${ }^{2}$
}

\begin{abstract}
ABSZTRAKT
A tanulmány egyrészt a közép-kelet-európai közigazgatási reformirányzatok fejlődését kívánja összefoglalni a rendszerváltástól kezdve, másrészt a következő időszakot a térségben is meghatározó techno-gazdasági trendekre tesz kitekintést. Az új közmenedzsment (NPM) és a poszt-közmenedzsment doktrínák elterjedését és alakulását az egyes országcsoportokban Drechsler és Randma-Liiv (2014) korszakolása alapján tekinti át. Ezt követően arra vállalkozik, hogy bemutassa a technológiai fejlődés okozta főbb kihívások és lehetőségek tág értelemben vett közigazgatási és kormányzati aspektusait. A vállalkozó állam koncepció beemelésével megmutatja, hogy az egyes átfogó problémák (wicked issues) megoldása aktív állami szerepvállalást igényel, amely várhatóan a közigazgatás reformirányainak alakulására is hatással lesz.
\end{abstract}

KULCSSZAVAK: közigazgatási reform, új közmenedzsment, poszt-közmenedzsment, techno-gazdasági paradigmák, vállalkozó állam

\section{ABSTRACT}

\section{Public administration reforms in Central-Eastern-Europe}

The goal of this paper is in one hand to summarize how public administration reform trends have spread in Central-Eastern-Europe since the transition, on the other hand to overview the techno-economical paradigms which can determine the near future in the region. To analyse spreading and development of New Public Management to Post-NPM doctrines periodization of Drechsler and Randma-Liiv (2014) is being used. At the end threads and opportunities related to technological development are aimed to be found in relation with public administration and governance. Using entrepreneurial state's concept shows that solving wicked issues needs active state's involvement, which might have a strong effect on public administration's reform as well. KEYWORDS: public administration reform, New Public Management, Post-NPM, technoeconomical paradigms, entrepreneurial state

${ }^{1}$ A mű a KÖFOP-2.1.2-VEKOP-15-2016-00001 azonosítószámú, „A jó kormányzást megalapozó közszolgálat-fejlesztés" elnevezésű kiemelt projekt keretében müködtetett Innovatív, Tanuló Közigazgatás Ludovika Kiemelt Kutatóműhely keretében, a Nemzeti Közszolgálati Egyetem felkérésére készült.

${ }^{2}$ Nemzeti Közszolgálati Egyetem Államtudományi és Közigazgatási Kar, Közszervezési és Infotechnológiai Tanszék, e-mail: szakos.judit@uni-nke.hu 


\section{KÖZELKÉP}

\section{Bevezetés}

A technológiai-gazdasági paradigmák okozta várható változások és a vállalkozó állam koncepció beemelésével megjelenő aktív állami szerepvállalás az egyes átfogó problémák megoldása kapcsán előrevetíti, hogy ezek a folyamatok várhatóan a közigazgatás reformirányainak alakulására is hatással lesznek. Ahhoz, hogy ezeket térségünk képes legyen adekvátan kezelni, szükséges megismerni a közigazgatási reformirányzatok kiindulási pontjait, fejlődési pályáját és sajátos nehézségeit is, hogy megfelelő alapokra lehessen építeni az átalakításokat.

Különösen fontos ez annak tükrében, hogy a globalizáció ${ }^{3}$ tovább erősíti azt a már 2007-ben megfogalmazott tételmondatot, miszerint az állampolgárok nem képesek eldönteni, hogy a kormány teljesítményének vagy a külső tényezőknek következménye a jólétük az adott időszakban (G. Fodor - Stumpf 2007). Ennek megfelelően pedig akár kételkedünk abban, hogy a kormányzati teljesítmény mérhető (Pesti 2004), akár az értékelés megvalósíthatósága mellett érvelünk (Gajduschek 2014), egyik álláspont sem jelenti azt, hogy ne kellene vitát folytatni arról, hogy mely állami feladatok teremtenek értéket a közösség számára, és azokat milyen módon kellene megvalósítani. Ehhez a párbeszédhez pedig - ismert korlátai figyelembevételével folyamatosan újabb és újabb eszközöket biztosít a digitalizáció, hiszen a gazdaságitársadalmi viszonyok dinamikája az államot is az adekvát válaszok újratervezésére készteti.

A trendek megértéséhez és új utak keresésének lehetőségéhez jelen tanulmány azzal kíván hozzájárulni, hogy egyrészt először rövid elméleti áttekintést ad a közigazgatási reformok témájáról, másrészt az új közmenedzsment és a neoweberiánus irányzatot is magába foglaló poszt-közmenedzsment doktrínák ${ }^{4}$ szerepével foglalkozik Közép-Kelet-Európában a releváns nemzetközi szakirodalom felhasználásával, kiemelve az új-közmenedzsment és a (neo)weberi megközelítés időben és térben váltakozó hangsúlyeltolódásaira. Említést tesz továbbá a modernizációhoz kötődő útkeresés kevésbé meghatározó kezdeményezéseiről is.

Végül a várható irányokat befolyásoló folyamatok áttekintésére tesz kísérletet azzal, hogy igyekszik bemutatni a technológiai fejlődés okozta fóbb kihívások és lehetőségek tág értelemben vett közigazgatási és kormányzati aspektusait.

A szerző bízik benne, hogy az áttekintés hozzájárul a korábbi reformok által determinált jelenlegi folyamatok megértéséhez és a jövőbeli tervezéshez.

\footnotetext{
${ }^{3}$ Vö. Boda (2006).

${ }^{4}$ A doktrína és az irányzat terminológia elhatárolása Rosta alapján: az új közmenedzsment és a poszt-közmenedzsment doktrína, míg például a neoweberiánus állam vagy az új közkormányzás irányzatok (Rosta 2015).
} 


\section{KÖZELKÉP}

\section{Közigazgatás és reform: elméleti alapok}

A közigazgatási reform definíciója a következőként határozható meg: „a közigazgatási szervezetek struktúrájának, folyamatának, és/vagy kultúrájának a szándékos változtatási kísérlete a (valamilyen értelemben történő) javítás irányába" (Pollitt Bouckaert 2017: 2). Itt a szerzők a meghatározásban - többek között - a közigazgatás hatékonyságának növelését, az ügyfelek ${ }^{5}$ iránti fokozottabb felelősségvállalást, továbbá a célok elérésére tett nagyobb erőfeszítést értik.

Hajnal (2004) foglalja össze, hogy a vonatkozó angol terminus, mellyel a később bemutatott elméletek is alapvetően operáltak, nem egyenlő a magyar közigazgatási reform kifejezéssel, annál tágabb kerettel foglalkozik: így a közigazgatás átfogóbb értelmezésével összefüggő reform is tágabb keretben értelmezhető.

Az egyes konkrét irányzatok megértését a következőkben összefoglalt multidiszciplináris elméleti alapok támasztják alá Jenei (2007) logikája mentén.

\subsection{A KÖZÖSSÉGI VÁLASZTÁS ELMÉLETE}

A közösségi választás (public choice) elméletekkel foglalkozó iskolák egyrészt a magánszektor múködését alapul véve, másrészt az önérdek-maximalizáló technokrácia múködését kritizálva dolgozták ki a közigazgatás lehetséges reformirányát. Kritikájuk alapja, hogy a közpolitikai döntéshozatalban a jellemzően saját érdekeit szolgáló bürokrácia kedvezőtlenül befolyásolja a közigazgatás múködését, mely így nem a közérdeket szolgálja.

Itt megjelenik a pártok szavazatmaximalizálási törekvése és a közintézmények folyamatos, öncélú növekedési törekvései. A közigazgatás és a politika ilyen irányú, egymást korlátozni nem tudó, sőt gyakran egymást támogató elhajlása ellen az elmélet szerint a verseny bevezetése szükséges, így valósítható meg a közjó. Niskanen (1973) szerint az önérdek e maximalizálása megfeleltethető a vállalkozások profitmaximalizáló magatartásának. Mueller (1979) szerint pedig a közgazdaságtan politikai tudományokban való alkalmazásaként értelmezhető a közösségi választás elmélete, így egyrészt a közszektor szereplőinek egyéni érdekmaximalizálását, másrészt a közigazgatási szervezetek mint egyének összességének figyelembevételét tartja kívánatosnak, bevonva a „homo oeconomicus” elméletet a párbeszédbe (Jenei 2007).

Bár empirikusan nem volt igazolható az elmélet minden tézise, fontos szerepe volt az új közmenedzsment irányzat kialakulásában (Rosta 2012).

\footnotetext{
${ }^{5}$ Ügyfél ebben a meghatározásban a közigazgatás szolgáltatásait igénybe vevő összes polgár.
} 


\section{KÖZELKÉP}

\subsection{NEOINSTITUCIONALISTA ELMÉLETI MEGKÖZELÍTÉSEK}

Az institucionalista elméletek az egyéb gazdasági és társadalmi tényezők mellett az intézményeknek is meghatározó szerepet tulajdonítanak. Az intézmények kényszerek, melyek szabályok és normák alapján megjelenő formális és informális jog, kötelezettség formájában jelenik meg. Ezzel együtt a neoinstitucionalizmus képviselői a politika és a gazdaság elválasztásának elméleti hátterével foglalkoznak, a piaci kudarcok mellett kiemelték a közintézményi kudarcok figyelembevételének fontosságát is.

Az elmélet szociológiai és közgazdaságtani irányzatait különböztethetjük meg. A szociológiai neoinstitucionalizmus szervezetelméleti alapokon nyugszik, alaptézisei szerint az intézmények és a társadalmi értékek elválaszthatatlanok, azonban előbbi hatása nagyobb a társadalmi interakciókra. A kudarcok minimalizálását hirdetik annak elkerülhetetlenségére hivatkozva, miközben a formális szabályok elsődlegességét tartják érvényesnek. Fejlődési pontként jelenik meg a fizikai infrastruktúra, a demográfiai struktúra és a történeti fejlődés állomásai, továbbá a köztisztviselők személyes hálózatai. Utóbbi a tanuló közigazgatás szempontjából fontos, attól függetlenül, hogy több kritikával is illették az irányzatot.

A másik irányzat a gazdasági neoinstitucionalizmus, amit az új intézményi közgazdaságtan képvisel. Itt megjelenik a megbízó-közvetítő elmélet (Moe 1984), mely összetett viszonyt egészíti ki az információs aszimmetria és a közösségi választásnál már megismert egyéni haszonmaximalizálás. Az irányzaton belül megkülönböztethetjük a tranzakciós költségek gazdaságtanát, mely szervezeti folyamatok vizsgálatával foglalkozik a közintézmények és a piac összehasonlítása tekintetében. Itt is megjelennek az információs kudarcok, a teljesítményértékelés nehézségei és a felek közötti bizalom hiánya.

A neoinstitucionalista irányzat legnagyobb gyengesége a túlzott egyszerűsítés, nem veszi figyelembe, hogy „a közintézmények működését szociális, kulturális, jogi és erkölcsi tényezők is befolyásolják" (Jenei 2007: 46).

\subsection{A KÖZSZOLGÁLATI ORIENTÁCIÓ}

A közszolgálati orientáció tana ${ }^{6}$ a közösségi választások egyik alternatívájaként kialakult nagyhatású irányzat, mely a helyi közintézmények megerősítését tűzte ki célul a humán erőforrás irányából - magába foglalva irányítási, motiválási és csoportmunkát érintő kérdéseket -, így biztosítva a kiemelkedő minőségű közszolgáltatásokat. Az irányzat elveti a közszektor teljes piacosítását, azonban bizonyos elemeket beépítendőnek tart. Mivel az irányzat a képviseleti és a közvetlen demokrácia eszkö-

\footnotetext{
${ }^{6}$ Public Service Orientation, PSO.
} 


\section{KÖZELKÉP}

zeit is ötvözi, bevezetése újszerű, közösségi igényekre fókuszáló megközelítéseket igényel. Gyakorlati alkalmazását azonban sokszor megnehezíti a köztisztviselők ellenállása, valamint az átképzés és információs technológiai beruházások pénzügyi korlátja.

A közszolgálati orientációban megjelenő magán- és közszféra modelljeinek jellemzőit foglalja össze a következő táblázat:

1. táblázat. A közszolgálati orientációban megjelenő köz- és magánszektorbeli jegyek

\begin{tabular}{|c|c|}
\hline Magánszektor modell & Közszektor modell \\
\hline egyéni döntés a piacon & kollektív döntés a politikában \\
\hline igény és ár & erőforrás-szükséglet \\
\hline egyéni cselekedetekre történő szorítkozás & nyitottság a közös cselekedetekre \\
\hline piaci méltányosság & a szükséglet méltányossága \\
\hline a piaci megelégedettség kutatása & az igazságosság kutatása \\
\hline fogyasztói szuverenitás & állampolgárság \\
\hline a verseny mint a piac eszköze & kollektív cselekvés, mint a politika eszköze \\
\hline a „kilépés” mint ösztönzés & a véleménynyilvánítás mint feltétel \\
\hline
\end{tabular}

Forrás: Pollitt (1993: 155)

\subsection{A 4 M-MODELL}

A reformpályák nemzetközileg elismert csoportosítását foglalja össze a négy M-modell, melynek különböző kombinációi figyelhetők meg a valóságban. A rövidítés fenntartás-megőrzés (maintain), modernizálás (modernize), piacosítás (marketise) és minimalizálás (minimalise) irányzatokra utal (Pollitt - Bouckaert 2017). Ezen belül a fenntartási és megőrzési reformpálya a hagyományos irányítás erősítését, feszesebb költségvetést és korrupcióellenességet, a pazarlás megszüntetését hirdeti - ez azonban nem jelenti az alkalmazkodás romlását, sok esetben épp ez segíti a változó körülményekhez való igazodást. A második, modernizációs pálya „a költségvetés-készítés, a számvitel, az emberierőforrás-gazdálkodás, a szervezeti működtetés és finanszírozás, valamint a szolgáltatások gyorsabb és rugalmasabb módját fejlesztik ki" (Jenei 2007: 23). Ez megvalósulhat a köztisztviselők deregulációs törekvései által, illetve az állampolgárok bevonásával. Az irányzat figyelembe veszi a társadalmi igényeket és fontosnak tartja a demokratikus legitimációt. A piaci mechanizmusok, értékorientációk és technikák közigazgatáson belüli alkalmazására építő harmadik fejlődési pálya a hatékonyságnövelés és a felelősség erősítése miatt többek között a verseny, a költség-összehasonlítás és az úgynevezett voucher rendszer használatával operál. A minimalizálás irányzata ezzel szemben nem a fent említett 


\section{KÖZELKÉP}

piaci eszközök közigazgatásba való beépítésével akar eredményeket elérni, hanem a közigazgatási feladatokat kívánja átadni a magánszféra szereplőinek. A kiszerződés és a privatizáció mint a minimalizálás leggyakoribb eszköze azonban magában hordozza az állam kiüresítésének veszélyét.

Nem jelenthető ki azonban egyik vagy másik irányzat elsőbbsége sem, mind rendelkezik előnyökkel és hátrányokkal is, gyakorlati alkalmazásukból pedig a közigazgatási reformok különböző típusai rajzolhatók ki: a minimalizálási és piacosítási pálya kombinációja jellemzi az új közmenedzsment ${ }^{7}$ elméletét. A megőrzési-modernizációs pálya pedig a neoweberiánus ${ }^{8}$ irányzat kialakulásához vezet el. Fontos ugyanakkor megjegyezni, hogy ezek az elméletek nem egy légüres térben formálódnak, az irányzatok megfelelő kérdésfeltevései, a hibákból és „vadhajtásokból” való tanulás, továbbá az egymás tevékenységére adott kritikus válaszok és reflexiók mind-mind a közigazgatási innovációt vitték előre.

\section{Közigazgatási reformirányzatok Közép-Kelet-Európában ${ }^{9}$}

A közép-kelet-európai régió ${ }^{10}$ fejlettsége és közös államszervezeti múltja összehasonlítható. A különböző reformirányzatok bevezetése is közel egy időben - azonban eltérő intenzitással és sikerességgel - valósult meg, így azok is vizsgálhatók a nemzetközi összehasonlítás módszerével. Az egyedi kiindulási pont, múltban megfigyelhető eltérő eredményesség, valamint útkeresés érdekes adalékul szolgálhat számunkra a 21. századi kihívásokra való reagálási minták jövőbeli elemzéséhez.

A térség országainak közös jellemzője, hogy a rendszerváltás előtti államszocializmusban nem alakult ki a modern értelemben vett államszervezet és a piacgazdaság. A reformirányzatok így egy ki sem alakult struktúrát kívántak jobbá tenni már azelőtt, hogy a szilárd alapok, gazdasági és jogrendszer, a piacgazdaság viszonyaihoz alkalmazkodni tudó társadalom és kultúra kialakulhatott volna. ${ }^{11} \mathrm{~A}$ társadalom, az

\footnotetext{
${ }^{7}$ New Public Management, NPM.

${ }^{8}$ Neo-Weberian State, NWS.

${ }^{9}$ A Közép-Kelet-Európa terminus a nemzetközi szakirodalom tükörfordítása.

${ }^{10}$ Jelen tanulmányban Közép-Kelet-Európa alatt az Európai Unióhoz 2004-2013 között csatlakozott tagországokat értem - Ciprus és Málta kivételével - azok földrajzi elhelyezkedésére és intézményi örökségére tekintettel. Ezen országok: Bulgária, Csehország, Észtország, Horvátország, Magyarország, Lettország, Litvánia, Lengyelország, Szlovákia, Szlovénia, Románia.

Drechsler - Randma-Liiv (2015) alapján ide értem továbbá Kelet-Németországot is posztszocialista múltja miatt, azon témák tekintetében, ahol megfelelő források elérhetőek az országrész közigazgatási reformjáról.

${ }^{11}$ Ezen viszonyok miatt lehetséges az országcsoportot egy blokként kezelve elemezni a továbbiakban azzal, hogy minden ország egyéni jegyekkel bír - és ahogy az államszocializmus idejében a közös alap mellett sem mutattak egységes képet, úgy a különböző reformirányzatok beépítése is más-más hatásokkal bírhat az egyes területeken.
} 


\section{KÖZELKÉP}

intézményrendszer és a kulturális háttér azonban minden országban befolyásolja a szakpolitika alkotás kimenetelének sikerét (Randma-Liiv 2007).

Az egyes doktrínák és hatások elemzésekor Drechsler és Randma-Liiv (2015) a következő korszakokat különbözteti meg: 1988 és 1996 között a transzformáció időszakáról beszélhetünk a régióban, minden országban széleskörű politikai, gazdasági és közigazgatási reform valósult meg. Ekkor már megjelent az új közmenedzsment irányzat, amely hatással volt a reformokra. A következő szakasz 1997 és 2004, illetve 2007 közé esik és az európai uniós csatlakozások időszakát foglalja magába. A közösséghez való csatlakozást követően kezdődött el a reformok finomhangolása a különböző irányzatok között. Összehasonlításként Nyugat-Európában a következő szakaszokat különbözteti meg a szerzőpáros: az 1980-as évektől teret nyer az új közmenedzsment doktrína, mely 1995 körül szenvedte az első törést, ekkor jelentek meg az első komoly kritikák. 2000 körül még mindig védhető volt a doktrína, de már empirikus bizonyítékok szóltak ellene. A szerzők megközelítése szerint azonban elveszítette hitelét az új közmenedzsment 2005 óta ${ }^{12}$ és a poszt-közmenedzsment irányzatainak virágkora kezdődött meg. Vizuálisan a két földrajzi egység fejlődését az 1. ábra foglalja össze. Itt egyértelmű időbeli megkésettség olvasható le a nyugat-európai és a térség országai között.

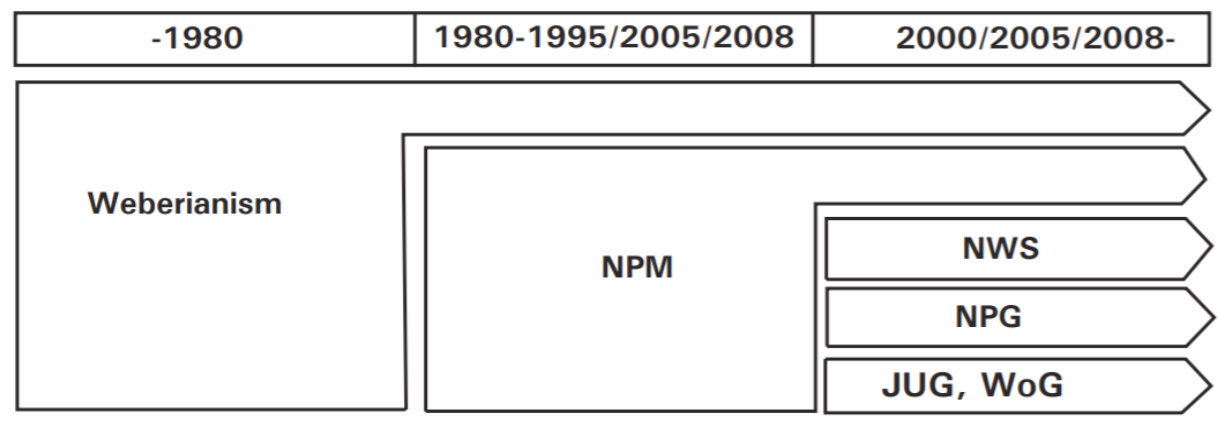

1. ábra. A közigazgatási reformirányzatok időbeli megjelenése Nyugat-, illetve Közép-Kelet-Európában. Forrás: Drechsler - Randma-Liiv (2015: 38)

Ma a technológiai és társadalmi változások ismételten új kihívások elé állították a közigazgatást, ami további változásokat, paradigmaváltást indukált. A tanulmány befejező része ezeket a trendeket kívánja felvillantani.

${ }^{12}$ Ez azonban nem tartja vissza a szakértők egy csoportját attól, hogy akár saját meggyőződése, akár saját érdekei miatt továbbra is ennek a doktrínának a bevezetését szorgalmazza.

Horváth M. (2011) ezzel szemben arról ír, hogy az új közmenedzsment az 1980-as években élte „hőskorát”, utána már csak egy menedzsment eszköztárrá változott, úgy, mint programtervezés, stratégiaalkotás stb. 


\section{KÖZELKÉP}

\subsection{TRANSZFORMÁCIÓS SZAKASZ (1989-1996)}

A közép-kelet-európai országokban bekövetkezett rendszerváltás után az országok reakciói nagyjából azonos mintát követtek. A vizsgált periódusban népszerű új közmenedzsment módszereinek adaptációja megfigyelhető valamennyi vizsgált országban. A korábban említett stabil államszervezet kiépítése nélkül történő reformirányzat-követés azonban több helyzeti sajátosságban gyökerezik.

A stabil átmenethez jó közigazgatási rendszerre, magasan képzett köztisztviselőkre, valamint a független állam koncepciójának megértésére van szükség - egyszerre, tehát a sikeres rendszerváltás mindhárom tényező megvalósulását feltételezi (Drechsler 2000). Ez azonban nem volt adott az időszakban. Ezzel analóg módon megjelenő probléma a nemzetközi gyakorlatokból történő tanulás módja. Randma-Liiv (2007) foglalja össze a különböző reformpolitikák rendszerváltás utáni mechanikus átvétele (policy transfer), illetve az ezekből való tanulás, a tanulságokból - jó és rossz példákból egyaránt - való országspecifikus irányok beépítése (policy learning) közötti különbséget és annak fő okait. A két mód közül az utóbbi képes az országspecifikus adottságokat figyelembe venni. Az egykori szocialista kelet-közép-európai országokban ugyanakkor jellemzően a mechanikus intézménytranszfer valósult meg, melynek fő okai az átmenet során az idő-, szakember-, tudás- és pénzhiányban keresendők.

Ezen belül az időkorlát úgy ragadható meg leginkább, ha belegondolunk: a rendszerváltások idején a folyamatok gyors és radikális átalakulással jártak, a kormányzatoknak kész, egyszerűen átemelhető megoldásokra volt szükségük, mintegy krízishelyzet analógiájára próbálták megoldani a kialakult helyzetet - tekintet nélkül a helyi társadalmi-gazdasági és bevezetési környezetre.

A szakemberhiány oka abban volt kereshető, hogy a korábbi közigazgatási dolgozóknak nem volt meg a szükséges tudásuk a demokratikus államszervezet múködtetésére. A rendszerváltás előtti „káderek” nem rendelkeztek megreformálható tudással és motivációval, ${ }^{13}$ így ezen a területen is kvázi újjáépítésről beszélhetünk (Drechsler - Randma-Liiv 2015). Ez egyrészt determinálta annak a lehetőségét, hogy a különböző szakpolitikák megfelelő implementáció mentén kerüljenek beépítésre, hiszen nem volt meg az elemzési kapacitás, másrészt külföldi szakértők bevonását tették indokolttá. A külföldi szakemberek azonban nem ismerték megfelelően a helyi viszonyokat ahhoz, hogy egy más országban bevált modellt megfelelően adaptáljanak. Továbbá érdekeltek voltak olyan rendszerek felépítésében, mely az ő munkájuknak és megélhetésüknek kedvez hosszú távon. Inverz módon ehhez kapcsolódik a tudáshiány is: az implementálni kényszerülők sok esetben csak az ország dokumentált jogi tételeit ismerték a követett nyugati mintának, annak kontextusát

${ }^{13}$ Jellemzően politikai és ideológiai hátterük volt erős. 


\section{KÖZELKÉP}

már nem, az ezen alapuló - konzultáció nélküli - szövegszerű átvétel pedig magában hordozza a körülményekhez való szerves alkalmazkodás hiányát.

Hozzáadódik mindezekhez a pénzhiány, mely szintén a „kész” modellek átvétele felé terelte a döntéshozókat, hiszen ezzel megspórolhatóak voltak az új metódusok kidolgozásával járó költségek. Gyakran a segélyek is e módszerek bevezetésével voltak párhuzamba állíthatók, így „kínálat alapúvá” vált a potenciális közpolitikák bevezetése közötti szelektálási lehetőség (Randma-Liiv 2007). Mind a Világbank, mind a Nemzetközi Valutaalap ezen meglévő minták átvételét szorgalmazta. Forráshiányra vezethető vissza az is, hogy nem állt rendelkezésre megfelelő erőforrás ahhoz, hogy versenyképes bérekkel építsenek ki felkészült közigazgatási állományt, mely azonban a sikeres államépítés egyik sarokköve. Megoldásként a hagyományos, weberi közszolgálati ethoszhoz tértek vissza, mely az elismerésre, a kiszámítható életpályamodellre és az ezzel járó biztonságra építkezik. Ebben a tekintetben tehát a közép-kelet-európai országok teljesen szembementek a NPM alapelveivel (Drechsler - Randma-Liiv 2015).

A fenti problémák ismerete mellett egyértelmű, hogy a rendszerváltás során mivel korábbi gyakorlatok nem léteztek az átmenetre - az abba kódolt hibák elkerülhetetlenek voltak, csak azok mértéke volt csökkenthető. ${ }^{14} \mathrm{Az}$ új közmenedzsment sok tekintetben tehát a legkézenfekvőbb megoldás volt, azonban annak „szerepét túlbecsülni, egy reformideológiaként implementálni az irányzatot és ezt tartani a fó célként a közigazgatási rendszer reformja során a rendszerváltó országokban egy alapvető hiba" (Nemec 2010: 31). A 2008-as gazdasági válsággal azok számára is bebizonyította az NPM, hogy önmagában még a nyugati országokban sem váltotta be a hozzá füzött reményeket, akik addig szkeptikusak voltak a kritikákkal szemben. ${ }^{15}$ A doktrínát érő legfőbb kritika, hogy nem látható hatékonysági, hatásossági és minőségi javulás a NPM-reformok következményeként (Noordhoek - Saner 2005), sőt az akár csökkent is a kiinduló eredményekhez képest (Pollitt - Dan 2013).

Maga az angolszász eredetű új közmenedzsment két szinten fogható meg: egyrészt üzleti, piaci elveket és módszereket emel át és épít be a magánszférából a közszférába az állam neoliberális felfogásának megfelelően, másrészt konkrét eszközöket és technikákat értünk alatta. Utóbbi módszerek lehetnek a teljesítménymenedzsment, az ügyfélközpontúság, a közszolgálati előmeneteli rendszer eltörlése, a közszféra és a magánszféra együttműködése, a hierarchikus szervezeti szintek csökkentése, a teljes körű minőségirányítás, a kiszerződés és a privatizáció. Később ez kibővült a decentralizáció, állampolgári bevonás és átláthatóság elveivel is

${ }^{14}$ Balázs (2011) munkájában foglalja össze a tudományos közösség által támogatott, nagy szakmai gondossággal kidolgozott kormányzati reformprogramokat, melyek igyekeztek fokozatosan a rendszerváltástól egészen 2006-ig az államigazgatási és az önkormányzati igazgatási diszfunkciókat korrigálni.

${ }^{15}$ Kivételt képez ez alól a CANZ-országokként is emlegetett: Kanada, Ausztrália és Új-Zéland. Azonban még itt is megfigyelhető egyfajta visszalépés, például Új-Zéland a 2000-es évek második felében visszavásárolta a vasúttársaságát (KiwiRail) (Drechsler - Randma-Liiv 2015). 


\section{KÖZELKÉP}

(Drechsler - Randma-Liiv 2015). A később megjelenő irányzatok is számos elemét felhasználták ennek az eszköztárnak, ezért látható, hogy az alapvető probléma nem feltétlenül az egyes módszerekben önmagukban keresendő.

Ugyanakkor azt is fontos kiemelni, hogy a két szféra motivációja különböző, a költségcsökkentés és a gyorsaság nem előzhet meg olyan, az állam felelősségi körébe tartozó demokratikus követelményeket, mint annak szabályozó szerepe, egyenlőségre törekvő irányultsága vagy a tisztességes eljárás alapelve (Drechsler Randma-Liiv 2015). Ez azonban - a korábban részletezett okokból kifolyólag, kevés kivétellel - nem tántorította el a közép-kelet-európai országokat az NPM-eszközök (2. ábra) minél szélesebb körének alkalmazásától, ezzel is bizonyítva elkötelezettségüket a Nyugat irányába.
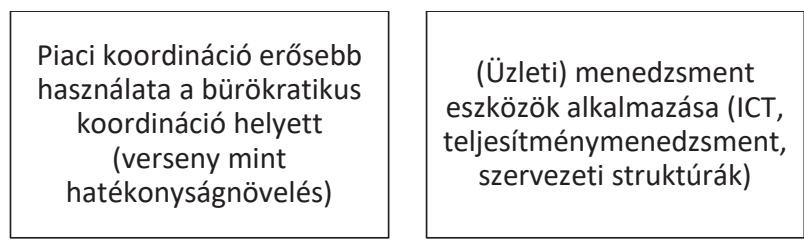

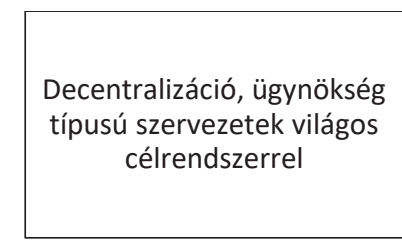

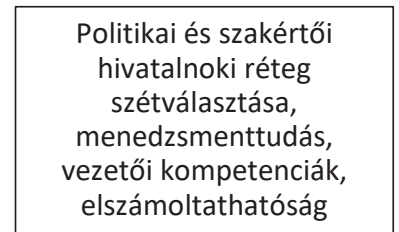

Politikai és szakértői hivatalnoki réteg szétválasztása, szetválasztasa, ezetői kompetenciák,

2. ábra. A NPM-doktrína legfőbb javaslatai

Forrás: Rosta (2015: 206) alapján saját szerkesztés
Eredményesség és hatékonyság mint a közigazgatási érték- és teljesítménymérés felértékelődése, ügyfélcentrikusság

\subsection{AZ EU-CSATLAKOZÁS ELŐKÉSZÍTÉSE (1997-2004/2007)}

Számos reform került beépítésre a csatlakozás előkészítésének időszakában, kiemelt figyelemmel a közösségi vívmányokra. ${ }^{16} \mathrm{~A}$ korábban, nemzetközi pénzügyi szervezetektől érkező, NPM-orientációjú nyomással szemben az Európai Unió tagjelölt országokkal szemben támasztott elvárásai alapvetően közelebb álltak a weberiánus, Rechtsstaat jellegú hagyományokhoz, mint az új közmenedzsment doktrínához. Közigazgatási alapelvként fogalmazták meg a jogbiztonságot, a megbízhatóságot és kiszámíthatóságot; a nyitottság és átláthatóság követelményét; a jogi elszámoltathatóságot; valamint a hatékonyság és eredményesség elvét (MeyerSahling 2011).

\footnotetext{
${ }^{16}$ Acquis communautaire.
} 


\section{KÖZELKÉP}

Részletesebben megvizsgálva, Meyer-Sahling (2011) a közigazgatás személyi állományával kapcsolatban tíz minimumfeltétel-csoportot írt le, amit a csatlakozni kívánó országoknak abban az időben ${ }^{17}$ teljesíteniük kellett:

- önálló közigazgatási stratégia (civil service policy) és ennek jogszabályba ültetése a pártatlanság, a jogi elszámoltathatóság és a jogi kiszámíthatóság alapelveivel;

- önálló egység a közigazgatáson belül az első pontban lefektetett stratégia központi koordinálására és menedzsmentjére. Megkötés nélkül alakíthattak ki ilyet a tagállamok, de az önálló szervezek és az ügynökségek alapítását erre a célra kiemelten támogatta az EU;

- nyilvánosan meghirdetett állások és verseny a közszolgálati pozíciókért a nyitottság, a hatékonyság és az egyenlő hozzáférés eléréséhez;

- kötelező, egységes írásbeli vizsga minden közigazgatásba jelentkezőnek, biztosítandó a teljesítmény alapú kiválasztást, az igazságos és egyenlő elbánást;

- különös figyelmet kapott a szakmaiság és a politikamentesség a közigazgatás felső vezetői között a pártatlanság biztosításához (a bérezésben is);

- védelem a köztisztviselők politikai alapon történő eltávolításának megelőzéséhez;

- átlátható és kiszámítható fizetési rendszer bevezetése a mérlegelési jogkör minimalizálásával, valamint olyan nagyságrend biztosításával, ami a tehetséges munkavállalókat képes a közigazgatáson belül tartani;

- átlátható és kiszámítható teljesítményértékelési rendszer, ami összhangba hozható a jutalmazási rendszerrel a fenti elvek megtartása mellett;

- a közigazgatásban dolgozók folyamatos képzésének biztosítása a hatékonyabb munkavégzés érdekében és a tréningekhez megfelelő feltételek megteremtése;

- a köztisztviselők jogainak és kötelezettségeinek deklarálása a szakmai integritás, a politikai semlegesség és a pártatlanság alapelveinek biztosításához.

Ezek a feltételek világosan követték a hagyományos bürokrácia elveit. Ezzel párhuzamosan az új közmenedzsment terjedése a közigazgatási struktúrában főként az ügynökségeken keresztül jelent meg. Közép-Kelet-Európában ez a szervezeti forma nem volt előzmény nélküli, már az 1980-as években is elterjedt volt. A vizsgált időszakban azonban további gyarapodás volt megfigyelhető, immár a modern demokrácia kiépítéséhez és az EU-hoz való csatlakozáshoz kapcsolódva.

${ }^{17}$ A követelményrendszer, amit a leendő tagországoknak kell teljesíteniük, azóta is csak minimális módosításokon ment keresztül. 
www. metszetek.unideb.hu

\section{KÖZELKÉP}

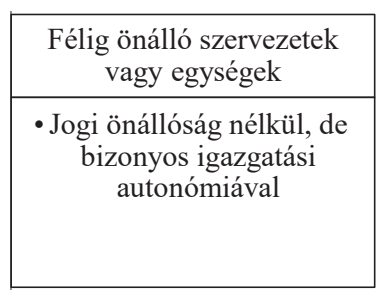

3. ábra. Ügynökségtípusok

A térségben a jogi önállóság nélküli szervezeti forma dominált ${ }^{18}$, illetve az ügynökségeknek delegált feladatok száma magas volt a vizsgált országokban, kivéve Magyarországon. Kritikaként megjelenik, hogy az ügynökségek kialakítása mögött nem volt valódi koncepció - ahogy a rendszerváltó országok közigazgatás-kialakítása mögött általában véve sem - és egy ad hoc jellegü, feladatbővülésre reflektáló, de nagymértékű szervezeti terjeszkedés kezdődött. A szervezetrendszer racionalizálása a 2000-es években kezdődött meg, országonként változó ütemben az ügynökségek túlburjánzására adott válaszreakcióként (U-turn) (Randma-Liiv - Nakrošis Hajnal 2011).

A Pollitt-Bouckaert-féle - korábban bemutatott - 4 M-modell pillérei közül az országcsoport a modernizáció útját követte a minimalizációra való törekvés beépítésével, azonban mindenhol országspecifikus megoldások is megjelentek (Van Thiel 2011).

\subsection{AZ EU-CSATLAKOZÁST KÖVETŐ INTÉZMÉNYRENDSZERI FEJLŐDÉS}

A csatlakozás után az új tagállamok egyrészt elkezdték finomítani a közigazgatási reformfolyamataikat, másrészt reagáltak a 2008-as globális pénzügyi válság közigazgatással szemben támasztott kihívásaira. Ugyanakkor azt is fontos hangsúlyoznunk, hogy az új tagállamok számára a tagság megszerzése után nem volt többé ösztönző erő arra, hogy a csatlakozáshoz teljesített feltételeket fenntartsák (Meyer-Sahling 2011). Kiemelendő továbbá, hogy a válságnak ugyan látható hatása volt, ez azonban nem indított meg alapvető strukturális reformokat. A kapcsolódó lépések többsége nem felelt meg a hosszú távra átgondolt, fenntartható és a korábbi vezetés hibáiból tanuló stratégia igényének, a másik oldalról pedig a megvalósult reformok nem köthetők közvetlenül a krízishez a legtöbb ország esetén (Randma-Liiv - Kickert 2017).

Ettől az időszaktól kezdve a közigazgatás személyi állományát tekintve három fejlődési utat figyelhetünk meg az egyes országoknál (4. ábra). A balti államokban a

\footnotetext{
${ }^{18}$ A lehetséges típusokról lásd a 3. ábrát.
} 


\section{KÖZELKÉP}

közigazgatás személyi állományának további fejlesztése figyelhető meg. Ezzel szemben Szlovákiát, Csehországot, Lengyelországot és Szlovéniát a visszafelé fordulás tendenciája jellemezte. Szlovákia például nyíltan bírálta az uniós követelményeket azok hatékonyság ellen ható és merev megközelítése miatt. Magyarország egyik csoportba sem illeszkedik, külön kategóriát alkot a Meyer-Sahling által vizsgált nyolc országból. Megfigyelése szerint itt egy erős, új közmenedzsment alapú reform bontakozott ki a 2000-es évek második felében (Meyer-Sahling 2011).

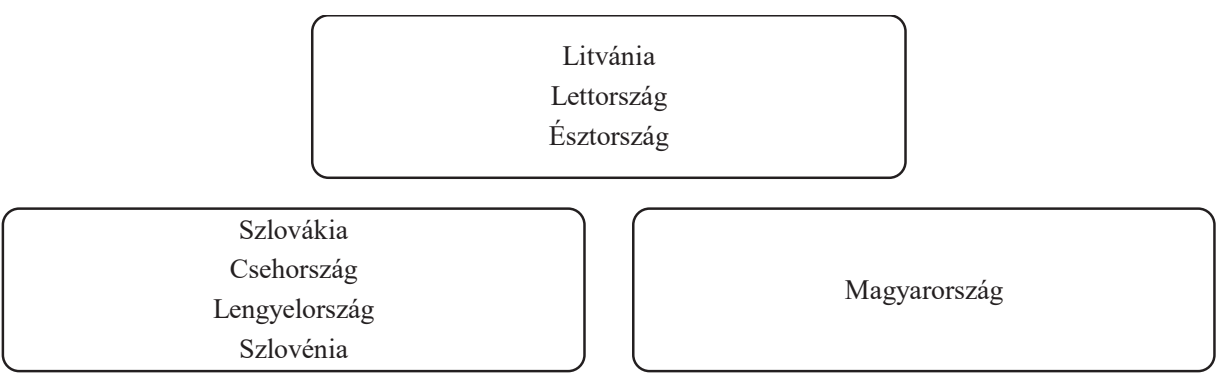

4. ábra. Országcsoportok az EU-csatlakozás utáni fejlődésük alapján

Forrás: Meyer-Sahling (2011: 234) alapján saját szerkesztés

Ezek az eltérő fejlődési pályák azonban nem jelentenek automatikusan problémát, minden esetben országspecifikusan és kritikával kell szemlélni a választott irányokat, ugyanis a reform léte önmagában sem jelent feltétlenül pozitív változást. Emellett a világban bekövetkezett változások is számos lépés megtételét követelték meg. Ilyen volt többek között az ügynökségek számának csökkentése vagy az infokommunikációs technológiák bevezetése a közigazgatásba (Drechsler - RandmaLiiv 2015).

Nyugat-Európához hasonlóan a vizsgált országcsoportban is megjelentek a poszt-közmenedzsmenthez kötődő különböző elméleti irányzatok, amelyek elsősorban a jobb koordinációt hivatottak elősegíteni. Az ezen belül megjelent neoweberiánus irányzat legfontosabb jegyei közé tartozik, hogy megtartotta az új közmenedzsment hasznosnak vélt menedzseri jegyeit, azonban visszanyúlt a hagyományos weberi bürokrácia gyökereihez. A 2008-as válság következményeként erősíteni kívánja az állami irányítást, a (pénzügyi) kontrollt és központosítást. A neoweberiánus megközelítés tehát az implementációra helyezi a fókuszt, míg ennek tükörképe, az új közkormányzás irányzata ${ }^{19}$ elsősorban a közpolitika-alkotásra koncentrál. További irányzatok közé tartozik a hozzáadott érték alapú kormányzás ${ }^{20}$, a koordinációra

\footnotetext{
${ }^{19}$ New Public Governance, NPG.

${ }^{20}$ Value/Value Added Governance.
} 


\section{KÖZELKÉP}

figyelő közös kormányzás ${ }^{21}$ vagy a teljes körű kormányzás ${ }^{22}$. Az irányzatok bősége - és a következő fejezetben ismertetett változások - miatt ma a közigazgatási reformok karaktere kissé zavarosnak tekinthető (Drechsler - Randma-Liiv 2015).

\section{A várható irányokat befolyásoló folyamatok}

Az egyes wicked issue-k, mint a globalizáció, a technológiai változások, a demográfiai és környezeti problémák mind proaktív magatartásra késztetik a kormányzatot is. Széles körben elfogadottálláspont, hogy a jog és a közigazgatás minden esetben csak követő magatartást végez, legyen szó akár a fenti tényezők valamelyikéről, akár a kutatók által szorgalmazott változási szükségszerúségekről.

A fenti trendek közül fontos részletesen elemezni a digitalizáció hatását, mely egyrészt egy új eszközrendszert, támogatást adhat az állam kezébe, másrészt a következőkben ismertetett problémákat is felveti, amire adekvát válaszokat kell találni. A technológiai változások kapcsán fontos látnunk, hogy a technológia és a közigazgatás kapcsolata nem modern kori sajátosság. Hajnal és Király (2014) egyrészt felhívják a figyelmet, hogy nem a semleges viszony, hanem egyrészt a kormányzat technológia fejlődésére tett befolyásolása kapcsán jelennek meg kutatások, másrészt arra vonatkozóan, hogy a technológia milyen változást indukál a kormányzásra és a közigazgatásra. A folyamatot az infokommunikációs szektorra szűkítve pedig megkülönböztetik a techno-szkeptikus és a techno-optimista megközelítéseket annak megfelelően, hogy milyen hatása lesz a közigazgatásra.

A közszektor számára megnyíló adatmennyiség nemcsak a gyakorló szakemberek munkáját tudja megváltoztatni, hanem a kutatók számára is minőségi változást jelenthet, hiszen valós időben nagy mennyiségű és olcsón vagy ingyen elérhető adat elemzése válik lehetővé. A big data ${ }^{23}$ megjelenése tehát megvalósíthatja a „növekvő képességünket, hogy hatalmas mennyiségű adatot állítsunk elő, gyűjtsünk, tároljunk és elemezzünk, ami át fogja formálni az egész politikai életről alkotott képünket." (Roberts - Golder 2015: 65) Az egyes techno-gazdasági paradigmák legjobb gyakorlatai pedig ebben a szektorban is utat törnek. Előretör a participáció és a nyílt kormányzás koncepciója (Budai et al. 2018).

Az adatgyűjtés a következő köz- és magánszolgáltatóktól származhat: $a$ ) a közösségi média adatok, amit az emberek önmaguk állítanak elő, b) az automatikusan előállított adatok a különböző szenzorokon keresztül, online, és $c$ ) a közigazgatás által, annak tevékenysége alatt gyűjtött adattömeg. Ez egyaránt jelent strukturált és nem strukturált adatokat, mely információ a kutatási design felépítésénél fontos. Az adat-

\footnotetext{
${ }^{21}$ Joint-Up Governance.

${ }^{22}$ Whole-of-Governance, WoG.

${ }^{23}$ Szintén használható kifejezés az adatelemzés („data analytics”) és az adattudomány („data science").
} 


\section{KÖZELKÉP}

gyűjtés és felhasználás azonban nem csak előnyökkel jár. A magánszféra és a személyes adatok védelme, a személyhez közvetlenül hozzákapcsolható adatok ${ }^{24}$ és profilkészítés ${ }^{25}$ problémája állami felelősség. A közjó elérését összhangba kell hozni és a szakembereknek tisztában kell lennie a köz- és magánszféra szolgáltatóira vonatkozó szabályozási keretrendszert, illetve az azt megelőző jogi, etikai és technológiai vitákat is. A felhasználás során pedig számolni kell ezen adatbázisok reprezentatív képességének korlátaival, mivel az interneten begyüjtött adatok nem reprezentálják többek között a hátrányos helyzetű csoportokat. Az internethez való hozzáférést összefüggésbe lehet hozni a bőrszínnel (race), az etnikai hovatartozással és a nemmel. Nem lehet tehát ezen adatok demokráciaerősítő célokra való felhasználása során - a reprezentáció téves látszatára alapozva - figyelmen kívül hagyni a kimaradó csoportok érdekeit. Mindenesetre megfelelő körültekintéssel felhasználva ezeket az adatokat számos valós idejű probléma elemezhetővé válhat és azokra így gyors válasz adható, mely lehetőség kihasználása mindenképpen fontos. A figyelembe veendő kérdések tehát: etikai vonatkozások, adatvédelmi kérdések (privacy), titoktartási és információbiztonsági problémák (secrecy and security concerns), hatékonyság (effectiveness) és megvalósíthatósági kérdések (feasibility and efficacy) (Mergel Rethemeyer - Isett 2016).

A közintézményi reformokat tárgyalva a számos további aspektusból kiemelném, hogy a megjelenő nagyobb információmennyiség a közigazgatás személyi állományában is változást fog eredményezni. Ez interdiszciplináris megközelítést igényel és kérdés, mely reformirányzat tud ennek adekvátan megfelelni. Drechsler (2020) álláspontja szerint a legsikeresebb e-közigazgatással bíró európai államok a weberiként számontartott megközelítést alkalmazzák.

Szintén Drechsler (2012) különbözteti meg a techno-gazdasági paradigmák kapcsán az „állam-távoli” (Staatsferne) és az „államközeli” (Staatsnähe) elhatárolást, ahol az innováció első szakaszában a hangsúly a vállalkozóké, az állam minél távolabb tartásával, míg a második esetben fontos szerep jut a kormányzatnak „az egyéb (piaci, politikai stb.) kockázatok terítése, társadalmasítása, illetve a profitmaximalizálás elősegítése" terén (Hajnal - Király 2014: 42).

Ezzel szemben az alapoktól változtatja meg az államról alkotott képünket Mazzucato, amikor az állam küldetéstudatát, értékválasztását hangsúlyozza. A közösségi választás elmélete ellenében bemutatja, hogy az állami beavatkozás nemcsak a piaci kudarcok kezelésének esetében lehet legitim, hanem lehetősége van egy aktív piacteremtő tevékenységre is stratégiai elvek és az általa kitűzött célok mentén a társadalmi problémák megoldására. Elveti azt az elméletet, miszerint az állam és a piac együttműködése csak az ösztönzésre, segítésre és kockázatcsökkentésre kell, hogy korlátozódjon. Olyan irány meghatározásában látja a lehetőséget, ahol a „kül-

\footnotetext{
${ }^{24}$ Personally identifiable information, PII.

${ }^{25}$ Vö. 15/1991. (IV. 13.) AB határozat.
} 


\section{KÖZELKÉP}

detésnek elég tágnak kell lennie ahhoz, hogy különböző szektorokat ösztönözzön (az ember holdra szállása is tucatnyi ágazat együttműködését igényelte), de elég konkrétnak is kell lennie ahhoz, hogy azt különböző megoldható problémákra lehessen bontani, így a küldetés folyamata rendszeresen ellenőrizhetővé váljon" (Mazzucato 2016: 141). Továbbá az államnak képesnek kell lennie viselnie a kockázatot, meg kell, hogy legyen benne az elhatározás és az ennek megfelelő szervezeti kultúra. A szerző a következő kutatási irányokat jelöli ki az állam gazdasági átalakulásban vállalt szerepeire vonatkozóan:

- küldetés alapú közpolitika-alkotás a tudomány és technológia területén;

- fejlesztő állam és fejlődésgazdaságtani kutatások területén;

- közgazdaságtani kutatás a technológiai pályák és a technológia-gazdaságtan területén;

- a vállalkozó állam kutatása kapcsán (Mazzucato 2016).

A holdra szállás példája is illusztrálja, hogy az aktív állami szerepvállalás ténye nem újkeletű, azonban annak békeidőben, különböző kihívásokra adható válaszok feltárására való adaptálása a kormányzat és a tág értelemben vett közigazgatás működésébe egy releváns perspektívát jelenthet a kutatásfejlesztés és innováció, valamint a technológiai változások, kiemelten az infokommunikációs technológiák kapcsán.

\section{Összegzés}

A közép-kelet-európai EU tagállamok fejlődési íve sajátos helyzetükből fakadóan eltérő úton, de ugyanabból az örökségből építkezve történt. A posztszocialista múlt hasonló módon determinálta a kezdeti erőforráskereteket és az országokba beérkező tudás felhasználásának lehetőségeit. Így bár az országok között találunk különbségeket, mind az Európai Unióhoz való csatlakozásig bejárt útjuk, mind a jelenleg jelentkező kihívások terén jelentős párhuzamokat azonosíthatunk. A vizsgált időszakban szignifikáns eltérés a csatlakozások lezárása utáni fejlődésben volt megfigyelhető, kiemelten Magyarország helyzetét, aki egyedüliként vezetett be erősen NPM-alapú kormányzást a 2000-es évek második felében.

Elméleti szinten látható az új közmenedzsment mint önálló doktrína kudarcának elismerése, azonban annak belátása is, hogy nem lehet minden általa alkalmazott eszközt automatikusan elvetni, hiszen - többek között - abból a legsikeresebbeket a későbbi irányzatok is átvették. A ma legnépszerübbnek tekinthető NWS is számos módszert alkalmaz ezek közül. A legutóbb megjelent irányzatok, melyek letisztulása most történik és amelyek között a fogalmi keretek kirajzolódása még csak folyamatban van, illetve amelyek között bizonyos fokú átfedés tapasztalható, szintén hatnak, vagy hatni fognak az állami szerepvállalásra. Ezek utóbbi években gyakorolt hatása 


\section{KÖZELKÉP}

az országcsoportra egy későbbi kutatás témáját tudja képezni. Ugyanígy, az Európai Unióhoz 2004 után csatlakozott, illetve tagjelölt országok fejlődésére is indokolt lehet kinyitni a kutatást a továbbiakban, ezek azonban jelen tanulmány kereteit meghaladják, egy jövőbeli munka részét képezik majd.

A legújabb trendek közigazgatásra való hatása, ennek az egyes reformirányzatokban való manifesztálódása pedig aktuális kérdés, a vállalkozó állam paradigmája vagy a technológiai változás indukálta digitalizáció kérdésköre is fontos determináló tényezőkként jelenhetnek meg. Az azonban egyértelműen látszik, hogy az irányok gondoljunk csak az e-közigazgatásra - már hatással vannak, és lesznek a jövőben is, valamint az ezekhez való alkalmazkodás, vagy az implementálás elmaradása alapvetően befolyásolhatja az országcsoporton belül megjelenő mintázatokat.

\section{Irodalom}

15/1991. (IV. 13.) AB határozat

Balázs I. (2011): A közigazgatás változásairól Magyarországon és Európában a rendszerváltástól napjainkig. Debreceni Egyetemi Kiadó, Debrecen

Boda Zs. (2006): A kormányzás jelentésváltozása a globalizáció korában: a governance-koncepció. In: A kormányzás kérdőjelei: Magyar Politikatudományi Társaság 2006 évi vándorgyűlése. Budapest, Magyarország: Magyar Politikatudományi Társaság (MPTT). http://politologia.ektf.hu/polvgy2006/eloadasok/boda_zsolt. doc (Utolsó letöltés: 2020.12. 02.)

Budai B. - Gerencsér B. Sz. - Veszprémi B. (2018): A digitális kor hazai közigazgatási specifikumai. Dialóg Campus Kiadó, Budapest

Drechsler, W. (2000): Public Administration in Central and Eastern Europe: Considerations from the 'state science' approach. In: Burlamaqui, L. - Castro, A. C. - Chang, H. J. (eds.): Institutions and the Role of the State. Edward Elgar Publishing, Cheltenham - Northampton, 267-279.

Drechsler, W. (2020): Good Bureaucracy: Max Weber and Public Administration Today. https://maxweberstudies.org/source/files/pdfs/Wolfgang-Drechsler. pdf (Utolsó letöltés: 2020. 12. 02.)

Drechsler, W. - Randma-Liiv, T. (2015): The new public management then and now: Lessons from the transition in central and eastern Europe. In: de Vries, M. Nemec, J. (eds.): Implementation of new public management tools. Experiences from transition and emerging countries. Bruylant, Brussels, 33-49.

Gajduschek Gy. (2014). Miben áll, és mérhető-e a kormányzati teljesítmény? Politikatudományi Szemle, 23(3): 97-116. 


\section{KÖZELKÉP}

G. Fodor G. - Stumpf I. (2007): A „jó kormányzás” két értelme. Avagy a demokratikus kormányzás programja és feltételei. Nemzeti Érdek, 1(3): 76-94.

Hajnal Gy. (2004): Igazgatási kultúra és New Public Management reformok egy öszszehasonlító esettanulmány tükrében. PhD-értekezés. Budapesti Közgazdaságtudományi és Államigazgatási Egyetem Gazdálkodás- és Szervezéstudományi Doktori Program, Budapest

Hajnal Gy. - Király A. (2014): Technológia és közigazgatás. In: Nemeslaki A. (szerk.): E-közszolgálatfejlesztés: Elméleti alapok és tudományos módszerek. Nemzeti Közszolgálati Egyetem, Budapest

Horváth M. T. (2011): A közmenedzsment változásai. In: Fazekas M. (szerk.) A közigazgatás tudományos vizsgálata egykor és ma. Gondolat, Budapest, 86-99.

Jenei Gy. (2007): Komparatív közpolitika. Elméleti megközelítések és nemzetközi esettanulmányok a közpolitika körében. Akadémiai doktori értekezés, Budapest

Mazzucato, M. (2016): From market fixing to market-creating: a new framework for innovation policy. Industry and Innovation, 23(2): 140-156.

Mergel, I. - Rethemeyer, R. K. - Isett, K. (2016): Big data in public affairs. In: Public Administration Review, 76(6): 928-937.

Meyer-Sahling, J. H. (2011): The durability of EU civil service policy in Central and Eastern Europe after accession. Governance, 24(2): 231-260.

Moe, T. M. (1984): The new economics of organization. American Journal of Political Science, 28(4): 739-777.

Mueller, D. C. (1979): Public Choice. Cambridge University Press, Cambridge

Nemec, J. (2010): New Public Management and its Implementation in CEE: What do we Know and where do we Go? NISPAcee Journal of Public Administration and Policy, 3(1): 31-52.

Niskanen, W. A. (1973): Bureaucracy--servant or master?: Lessons from America. Institute of Economic Affairs, London

Noordhoek, P. - Saner, R. (2005): Beyond new public management. Answering the claims of both politics and society. Public Organization Review, 5(1): 35-53.

Pesti S (2004): Mérhető-e a kormányzati teljesítmény. Politikatudományi Szemle, 13(1-2): 233-253.

Pollitt, C. (1993): Managerialism and the Public Services. Blackwell Publishers, Oxford

Pollitt, C. - Bouckaert, G. (2017): Public Management Reform: A Comparative Analysis - Into the Age of Austerity. Oxford University Press, Oxford 


\section{KÖZELKÉP}

Pollitt, C. - Dan, S. (2013): Searching for impacts in performance-oriented management reform: A review of the European literature. Public Performance \& Management Review, 37(1): 7-32.

Randma-Liiv, T. (2007): From policy transfer to policy learning in Central and Eastern Europe. In: Coombes, D. - Vass L. (eds.): Post-Communist Public Administration: Restoring Professionalism and Accountability. NISPAcee Press, Bratislava 27-36.

Randma-Liiv, T. - Nakrošis, V. - Hajnal Gy. (2011): Public sector organization in Central and Eastern Europe: from agencification to de-agencification. Transylvanian Review of Administrative Sciences, 7(SI): 160-175.

Randma-Liiv, T. - Kickert, W. (2017): The impact of the fiscal crisis on public administration reforms: Comparison of 14 European countries. Journal of Comparative Policy Analysis: Research and Practice, 19(2): 155-172.

Roberts, C. W. - Golder, M. (2015): Big data, Casual inference, and Formal Theory: Contradictory Trends in Political Science. Political Science and Politics, 48(1): 65-70.

Rosta M. (2012): Az új közszolgálati menedzsment célja. Társadalomkutatás, 30(2): 169-185.

Rosta M. (2015): Kakofónia a közmenedzsmentben. A New Public Management és a Post-New Public Management kapcsolata. Köz-gazdaság: tudományos füzetek, 10(3): 205-217.

Van Thiel, S. (2011). Comparing agencification in Central Eastern European and western European countries: Fundamentally alike in unimportant respects? Transylvanian Review of Administrative Sciences, 7(SI): 15-32. 